\title{
Characterization and Impact of Waste Plastic Oil in a Variable Compression Ratio Diesel Engine
}

\author{
Khatha Wathakit ${ }^{1}$, Ekarong Sukjit ${ }^{1}$, Chalita Kaewbuddee ${ }^{2}$, Somkiat Maithomklang ${ }^{1}$, Niti Klinkaew ${ }^{1}$, \\ Pansa Liplap ${ }^{1}$, Weerachai Arjharn ${ }^{1}$ and Jiraphon Srisertpol ${ }^{1, *}$ D \\ 1 Institute of Engineering, School of Mechanical Engineering, Suranaree University of Technology, Muang \\ Nakhon Ratchasima District, Nakhon Ratchasima 30000, Thailand; vkata@sut.ac.th (K.W.); \\ ekarong@g.sut.ac.th (E.S.); somkiatmaithomklang@gmail.com (S.M.); niti_klinkaew@g.sut.ac.th (N.K.); \\ pansa@sut.ac.th (P.L.); arjharh@g.sut.ac.th (W.A.) \\ 2 Faculty of Industrial Technology, Surindra Rajabhat University, 186 Moo 1 Surin-Prasat Road, Nokmuang \\ Sub-District, Muang District, Surin 32000, Thailand; chalita.k@srru.ac.th \\ * Correspondence: jiraphon@sut.ac.th
}

Citation: Wathakit, K.; Sukjit, E.; Kaewbuddee, C.; Maithomklang, S.; Klinkaew, N.; Liplap, P.; Arjharn, W.; Srisertpol, J. Characterization and Impact of Waste Plastic Oil in a Variable Compression Ratio Diesel Engine. Energies 2021, 14, 2230. https://doi.org/10.3390/en14082230

Academic Editor: Constantine D. Rakopoulos

Received: 1 March 2021

Accepted: 14 April 2021

Published: 16 April 2021

Publisher's Note: MDPI stays neutral with regard to jurisdictional claims in published maps and institutional affiliations.

Copyright: (c) 2021 by the authors. Licensee MDPI, Basel, Switzerland. This article is an open access article distributed under the terms and conditions of the Creative Commons Attribution (CC BY) license (https:// creativecommons.org/licenses/by/ $4.0 /)$.

\begin{abstract}
The characterization of pyrolysis oil obtained from mixed waste plastics and its utilization in a compression ignition engine were investigated. The chemical compositions and physicochemical properties of distilled waste plastic oil (WPO) and crude waste plastic oil (CWPO) were analyzed. The experiment was conducted with a variable compression ratio diesel engine at various loads and compression ratios to evaluate combustion characteristics, exhaust emissions, and engine performance. The experimental results show that CWPO contains the highest percentage of carbon atoms in the C4-C11 group, while WPO contains the highest percentage of carbon atoms in the C12-C20 group, similar to the main compositions of diesel fuel. According to the preliminary study in chemical compositions and physicochemical properties, WPO and diesel fuel were selected for the engine test at different compression ratios of 16,17 , and 18 and different engine operating loads of $25 \%, 50 \%$, and $75 \%$ of maximum engine torque at an engine speed of $1500 \mathrm{rpm}$. It was found that increasing the engine operating load and the compression ratio tends to increase the brake thermal efficiency. Increasing the compression ratio results in a significantly shorter delay time in a combustion state. A lower cetane index and a higher percentage of long chain carbon compounds (C12-C20) could be the main factors affecting higher $\mathrm{NOx}, \mathrm{CO}$, and $\mathrm{HC}$ emissions with the combustion characteristics of WPO, compared to diesel fuel. The disadvantage of emissions by the use of WPO can be alleviated when the engine is running at maximum load and a high compression ratio.
\end{abstract}

Keywords: waste plastic oil; compression ratio; emission; diesel engine

\section{Introduction}

Fuels for energy is very important to industry, transportation, and agriculture. Currently, the fluctuation of fuel price conditions affects the cost of production and the country's development in various fields. Therefore, the government has promoted the use of renewable energy as an alternative to incentivize people to use other fuels, to replace diesel fuel and to reduce the demand for oil. Thailand mainly relies on imported energy from abroad, because it is unable to increase the domestic production of petroleum to meet demand. The development of renewable energy will seriously reduce the dependence on and import of fuels [1]. Thailand has continued to increase the use of renewable energy as a result of alternative energy development policies with the goal of increasing the use of renewable energy in all sectors of society and reducing the consumption of energy from fossil fuels. This will also reduce the import of energy from abroad [2,3]. Moreover, Thailand is faced with a large amount of solid waste. Large, medium, and small cities all face unsanitary waste management issues that affect the environment. Data on the situation of waste in Thailand show that, in 2018, there were approximately 27.93 million 
tons of waste, with a rate of solid waste of $1.15 \mathrm{~kg}$ per person per day. Approximately $39 \%$ of the total solid waste (10.85 million tons) and 35\% of solid waste (about 9.76 million tons) generated has been properly disposed. Approximately 7.32 million tons of solid waste have been improperly handled [4]. Generated plastics are about $12 \%$ of the total waste and take a long time to decompose [5]. Therefore, engineering waste management is necessary because, at present, there is technology to effectively manage this waste. One technology that has received attention is oil production technology from plastic waste through the pyrolysis process, due to its potential to convert plastic waste to energy in petroleum-based fuel. This is in line with the National Energy Integration Framework of the Ministry of Energy, devised to develop energy strategic plans in the name of the TIEB (Thailand Integrated Energy Blueprint) 2015-2036, which pays attention to energy security, economic, and environmental aspects of society [3].

Pyrolysis is the process of chemically cycle-debasing long chain polymer particles into small chain hydrocarbons in the absence of air or oxygen at the relatively high temperature range of $300-500{ }^{\circ} \mathrm{C}$ [6]. The three significant products from those pyrolysis methodologies are liquid, gas, and char, while the quantity of each product largely depends on such parameters as the type of feedstock and on pyrolysis procedure parameters, such as temperature, the type of reactor, pressure, residence time, heating rate, and the type of catalyst [7]. With respect to the feedstock, plastic waste mainly consists of high-density polyethylene (HDPE), low-density polyethylene (LDPE), polyethylene terephthalate (PET), polyethylene $(\mathrm{PE})$, polystyrene (PS), polypropylene (PP), and polyvinyl chloride (PVC). Studies on the thermal degradation temperature of common plastic materials under thermogravimetric analysis have revealed that degradation begins at a temperature depending on the plastic type and the heating rate. The breakage of carbon chains was induced at a temperature above $325^{\circ} \mathrm{C}$ for HDPE and was completed at about $470{ }^{\circ} \mathrm{C}$. Additionally, the degradation process was accelerated at a higher heating rate. The lowest temperature of the starting degradation was obtained with PS. It has been suggested that all plastics initiate degradation at a temperature below $400{ }^{\circ} \mathrm{C}$ [8]. The liquid oil derived from the pyrolysis of various types of plastic waste contain physical and chemical properties similar to those of fossil fuel [9-12]. Therefore, waste plastic oil (WPO) is favorably appropriate to be developed as an alternative fuel in internal combustion engines [13].

Several experiments have been conducted on the use of plastic waste derived as a fuel in compression ignition diesel engines. Previous investigations of using WPO in diesel engines compared with diesel fuel operation are summarized in Table 1. Most of the investigations show similar trends of increase in brake-specific fuel consumption and brake thermal efficiency, with increasing concentrations of WPO in blends of diesel and WPO. Moreover, oxides of nitrogen (NOx), unburnt hydrocarbon (HC), and carbon monoxide $(\mathrm{CO})$ tend to increase with the use of WPO. In a recent work, Kalargaris et al. [14] studied the effect of pyrolysis oil from polypropylene on the characteristics of combustion, exhaust emissions, and engine performance at different temperatures of the pyrolysis process in a diesel engine. The experiments showed that the pyrolysis oil promoted steady engine operation with a longer combustion duration, a lower engine performance, a higher NOx and HC, and lower CO emissions when compared with the engine operating on diesel fuel. Venkatesan et al. [15] studied the combustion characteristics and the engine performance of a diesel engine fueled with WPO blends. The brake thermal efficiency (BTE) for the WPO blends was found to be slightly higher than that of the diesel fuel. The engine performance and combustion characteristics of the diesel engine were significantly affected by the physical and chemical properties of WPO. Furthermore, at the highest load conditions, WPO blends yield better results in comparison to diesel fuel with respect to peak pressure, the rate of pressure rise, in-cylinder pressure, and the rate of heat release. The use of WPO as an alternative fuel in diesel engines tends to result in an increase in BTE, NOx, and smoke emissions, while BSFC, CO, and HC emissions decrease with an increasing engine load [16-22]. 
Table 1. Summary of previous investigations on using waste plastic oil (WPO) in diesel engines compared with diesel fuel operation.

\begin{tabular}{|c|c|c|c|c|c|c|c|c|c|c|}
\hline \multirow{2}{*}{$\begin{array}{l}\text { Diesel Engine } \\
\text { Specifications }\end{array}$} & \multirow{2}{*}{ Types of Fuel } & \multicolumn{2}{|c|}{ Performance } & \multicolumn{2}{|c|}{ Combustion } & \multicolumn{4}{|c|}{ Emissions } & \multirow{2}{*}{ Ref. } \\
\hline & & BSFC & BTE & ICP & RoHR & $\mathrm{NO}_{\mathrm{X}}$ & $\mathrm{CO}$ & $\mathrm{HC}$ & Smoke & \\
\hline $\begin{array}{l}\text { AKSA-A4CRX46TI, } \\
\text { 4-cylinder, 4-stroke, } \\
68 \mathrm{~kW} \text { at } 1500 \mathrm{rpm}\end{array}$ & WPO & - & $\downarrow$ & $\uparrow$ & $\uparrow$ & $\uparrow$ & $\uparrow$ & $\uparrow$ & - & [14] \\
\hline $\begin{array}{l}\text { Kirloskar AV1, DI, } \\
\text { 1-cylinder, 4-stroke, } \\
3.7 \text { kW at } 1500 \text { rpm }\end{array}$ & WPO & $\uparrow$ & $\uparrow$ & $\uparrow$ & $\uparrow$ & $\uparrow$ & $\uparrow$ & 4 & $\uparrow$ & [16] \\
\hline $\begin{array}{l}\text { AKSA1-A4CRX46TI, } \\
\text { 4-cylinder, 4-stroke, } \\
68 \mathrm{~kW} \text { at } 1500 \mathrm{rpm}\end{array}$ & WPO & $\uparrow$ & $\downarrow$ & $\uparrow$ & $\uparrow$ & $\uparrow$ & $\uparrow$ & 4 & $\uparrow$ & [17] \\
\hline $\begin{array}{c}\text { 4JA1, DI, } \\
\text { 4-cylinder, 4-stroke, } \\
68 \mathrm{~kW} \text { at } 1500 \mathrm{rpm}\end{array}$ & WPO & $\uparrow$ & $\downarrow$ & $\downarrow$ & 4 & $\uparrow$ & $\uparrow$ & $\uparrow$ & $\downarrow$ & [18] \\
\hline $\begin{array}{l}\text { Kirloskar TAF1, DI, } \\
1 \text {-cylinder, } 4 \text {-stroke, } \\
4.4 \mathrm{~kW} \text { at } 1500 \mathrm{rpm}\end{array}$ & WPO & $\downarrow$ & $\uparrow$ & - & - & $\uparrow$ & $\uparrow$ & 4 & - & [19] \\
\hline $\begin{array}{c}\text { Eicher E483, DI, } \\
\text { 4-cylinder, 4-stroke, } \\
\text { Max. Power } 70 \text { kW }\end{array}$ & WPO & $\downarrow$ & $\uparrow$ & $\uparrow$ & $\uparrow$ & $\uparrow$ & $\uparrow$ & $\uparrow$ & $\uparrow$ & [20] \\
\hline $\begin{array}{l}\text { Kirloskar TV1, DI, } \\
\text { 1-cylinder, 4-stroke, } \\
5.2 \mathrm{~kW} \text { at } 1500 \mathrm{rpm}\end{array}$ & WPO & $\downarrow$ & $\uparrow$ & - & - & $\uparrow$ & $\uparrow$ & $\uparrow$ & 4 & [21] \\
\hline $\begin{array}{c}\text { DI, Turbocharger, } \\
\text { 4-cylinder in line T/C, } \\
\text { 4-stroke, } 70 \mathrm{~kW}\end{array}$ & WPO & $\downarrow$ & $\uparrow$ & $\uparrow$ & $\uparrow$ & $\uparrow$ & $\uparrow$ & 4 & - & [22] \\
\hline $\begin{array}{c}\text { DI, 1-cylinder, } \\
\text { 4-stroke, } \\
3.7 \mathrm{~kW} \text { at } 1500 \mathrm{rpm}\end{array}$ & WPO & - & $\downarrow$ & $\uparrow$ & $\uparrow$ & - & - & - & - & [23] \\
\hline $\begin{array}{c}\text { Lombardini-Kohler } \\
\text { FOCS 1.4, } \\
\text { IDI, 1-cylinder, } \\
\text { 4-stroke, }\end{array}$ & WPO & $\downarrow$ & $\uparrow$ & $\downarrow$ & $\downarrow$ & - & - & - & $\downarrow$ & [24] \\
\hline $\begin{array}{l}\text { Kirloskar TAF1, DI, } \\
\text { 1-cylinder, 4-stroke, } \\
4.4 \mathrm{~kW} \text { at } 1500 \mathrm{rpm}\end{array}$ & WPO & - & $\downarrow$ & $\uparrow$ & $\uparrow$ & $\uparrow$ & - & $\uparrow$ & $\uparrow$ & [25] \\
\hline $\begin{array}{l}\text { AKSA-A4CRX46TI, } \\
\text { 4-cylinder, 4-stroke, } \\
68 \mathrm{~kW} \text { at } 1500 \mathrm{rpm}\end{array}$ & WPO & $\uparrow$ & $\downarrow$ & $\uparrow$ & $\uparrow$ & $\uparrow$ & $\uparrow$ & $\uparrow$ & - & [26] \\
\hline $\begin{array}{c}\text { DI, 1-cylinder, } \\
\text { 4-stroke, } 3.7 \mathrm{~kW} \text { at } \\
1500 \mathrm{rpm}\end{array}$ & WPO-RME & $\uparrow$ & $\uparrow$ & $\downarrow$ & $\downarrow$ & - & - & - & - & [27] \\
\hline $\begin{array}{l}\text { Kirloskar TV1, DI, } \\
\text { 1-cylinder, 4-stroke, } \\
3.5 \text { kW at } 1500 \text { rpm }\end{array}$ & $\begin{array}{l}\text { WPO-POME } \\
\text { WPO-COME }\end{array}$ & $\uparrow$ & $\boldsymbol{\uparrow}$ & $\downarrow$ & $\downarrow$ & $\downarrow$ & $\uparrow$ & $\downarrow$ & $\uparrow$ & [28] \\
\hline $\begin{array}{l}\text { Kirloskar TAF1, DI, } \\
\text { 1-cylinder, } 4 \text {-stroke, } \\
4.4 \mathrm{~kW} \text { at } 1500 \mathrm{rpm}\end{array}$ & WPO-BU & $\downarrow$ & $\uparrow$ & - & - & $\uparrow$ & $\uparrow$ & 4 & $\downarrow$ & [29] \\
\hline
\end{tabular}

$\uparrow_{\text {_increases, }} \downarrow$ _decreases, WPO—waste plastic oil, RME—rice bran methyl ester, POME—palm methyl ester, COME—castor methyl ester, BU—Butanol, DI-Direct injection. 
Currently, there is an increasing amount of research on alternative fuels for engines, and due to energy, environmental, and economic problems, it is necessary to encourage studies on alternative fuels to reduce the amount of primary fuel consumption. For the adoption of WPO gained from the pyrolysis process for compression ignition engines, it is necessary to study the effects of various factors. Therefore, this research aims to investigate the effects of changes in the compression ratio on the characteristics of combustion, exhaust emissions, and engine performance when using WPO as an alternative fuel in a variable compression ratio diesel engine. The outcome of this research can promote WPO as an alternative fuel for diesel engines and accords with alternative energy development plans in Thailand.

\section{Materials and Methods}

\subsection{Fuels}

In this work, crude waste plastic oil (CWPO) and distilled waste plastic oil (WPO) obtained by fractional distillation were studied. The mixed plastic waste used as feedstock in the pyrolysis process was collected from Nakhon Ratchasima, Thailand, and included bags, bottles, and other products made of plastic. The diesel fuel was commercial diesel fuel (B7), which is diesel fuel containing 7\% biodiesel by volume, according to the Ministry of Energy. The master plant that processes mixed waste plastic into fuel by pyrolysis is located at Suranaree University of Technology.

Pyrolysis is the thermal decomposition of plastics in the absence of air or oxygen. Waste plastics are gently cracked by adding a catalyst, and the gases are condensed in a series of condensers to yield a low-sulphur distillate [28]. The pyrolysis reactor system is of a continuous vertical type. The plastic waste from the MBT system was used as a raw material for fuel production. The principle of operation is that the plastic scraps are conveyed to a screw feeder at a rate of approximately $250 \mathrm{~kg} / \mathrm{h}$, where the screws are preheated to allow the plastic to melt and be ready to evaporate as a vapor when heated up. After that, the liquid plastic flows into the reactor and then the continuous stirred tank reactor, where the reactor is temperature-controlled at $350-400{ }^{\circ} \mathrm{C}$. When the plastic changes from liquid to vapor, it flows into the fractional distillation tower at a temperature of $340^{\circ} \mathrm{C}$, and at this distillation tower, it separates the heavy and light oil vapor molecules. After that, the oil vapor enters the condenser and flows into the oil/water separator, and the oil that is produced, i.e., CWPO, will flow into the storage tank. We used an oil distillation system to improve the quality of liquid fuels from plastic waste by using a vacuum separation tower to separate the mixtures into the form of individual elements (fractions). The middle fraction or diesel fuel, i.e., WPO, is taken from the center of the distillation tower, and the lighter part (the light fraction) or gasoline is released from the top of the distillation tower.

\subsection{Gas Chromatography Analysis}

Gas Chromatography-Mass Spectrometry (GC-MS) is extensively used as a method for the chemical characterization of the fuels. The presence of the compound identification of test fuels was used to determine the chemical compositions. One microliter was injected into a GC-MS system equipped with a DB-wax capillary column of a length of $60 \mathrm{~m}$, an internal diameter of $0.25 \mathrm{~mm}$, and a film thickness of $0.25 \mu \mathrm{m}$. The operating conditions were as follows: The helium gas flow rate of approximately $1.0 \mathrm{~mL} / \mathrm{min}$ was utilized as a carrier gas. The temperature of the GC oven was performed in a temperature-programmed mode at $70{ }^{\circ} \mathrm{C}$ for $3 \mathrm{~min}$, raised at $3{ }^{\circ} \mathrm{C} / \mathrm{min}$ to $180{ }^{\circ} \mathrm{C}$, and finally ramped to $250{ }^{\circ} \mathrm{C}$ (held for $25 \mathrm{~min}$ ) at a heating rate of $10^{\circ} \mathrm{C} / \mathrm{min}$. The inlet gas temperature was maintained at $250{ }^{\circ} \mathrm{C}$ with a separation ratio of $20: 1$. The mass spectra detector was operated in a mass range from 35 to $550 \mathrm{~m} / \mathrm{z}$ with a $250{ }^{\circ} \mathrm{C}$ source [28]. GC-MS data are often demonstrated as total ion current (TIC) intensity. The data obtained from TIC can be used to identify the chemical composition of the test fuels. 


\subsection{Experimental Setup and Procedure}

The study on combustion and emissions characteristics was conducted using a variable compression ratio (VCR) diesel engine, a single-cylinder and four-stroke engine with a direct fuel injection system. The air was naturally induced to the combustion chamber, while water and a water-cooling system were used to control the temperature of the engine. The engine was coupled with an eddy current dynamometer to provide the engine load. The technical specifications of the engine used for the investigations are described in [28]. A schematic diagram of the experimental installation is shown in Figure 1. The engine operated at $1500 \mathrm{rpm}$ with three different engine loads $(25 \%, 50 \%$, and $75 \%$ of the maximum engine torque) under compression ratios of 16,17 , and 18 . The fuel consumption of the engine was calculated by the fuel volume and testing time, which were recorded by a burette and stopwatch, respectively.

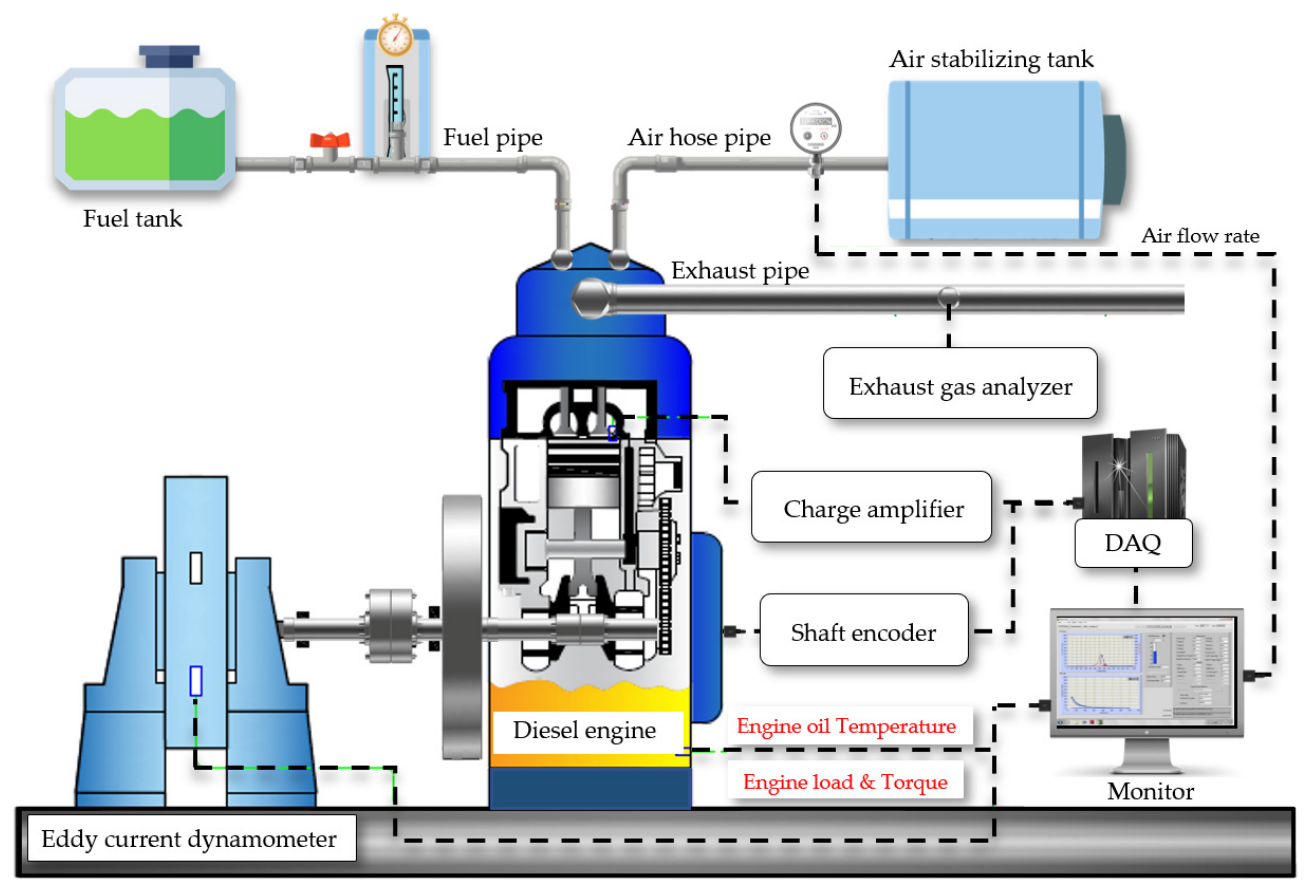

Figure 1. A schematic diagram of the experimental installation.

EngineSoft software was used to analyze the combustion characteristics. A data acquisition card (DAQ) placed between the engine and computer converted the analog signal to a digital value. The PCB Piezotronics pressure transducer was mounted on the cylinder head for the measurement of the in-cylinder pressure. A Kubler crank angle sensor was used to detect the engine crank angle. The in-cylinder pressure data were averaged for 100 cycles in succession at each crank angle. A Testo 308 smoke tester was used to determine smoke emissions, and a Testo 350 flue gas analyzer was applied to determine carbon monoxide $(\mathrm{CO})$, nitrogen oxides $(\mathrm{NO})$, and hydrocarbon $(\mathrm{HC})$. The technical specifications of the exhaust gas analyzer are shown in Table 2.

Table 2. Specifications of the engine exhaust gas analyzer.

\begin{tabular}{ccccc}
\hline Parameter & Measuring Techniques & Measuring Range & Resolution & Accuracy \\
\hline TESTO 350 & & & & \\
$\mathrm{NO}$ & Chemiluminescence & $0-4000 \mathrm{ppm}$ & $1 \mathrm{ppm}$ & $\pm 5<100 \mathrm{ppm}$ \\
$\mathrm{NO}_{2}$ & Chemiluminescence & $0-500 \mathrm{ppm}$ & $0.1 \mathrm{ppm}$ & $\pm 5<100 \mathrm{ppm}$ \\
$\mathrm{CO}$ & Nondispersive Infrared & $0-10,000 \mathrm{ppm}$ & $1 \mathrm{ppm}$ & $\pm 10<200 \mathrm{ppm}$ \\
$\mathrm{HC}$ & Flame Ionization Detector & $0-40,000 \mathrm{ppm}$ & $10 \mathrm{ppm}$ & $\pm 400 \mathrm{ppm} \quad \pm 0.2$ \\
TESTO 308 & Photodiode (filter paper) & $0-6$ & 0.1 & \pm 0.1 \\
Smoke index & & &
\end{tabular}


The measurements of the various parameters were recorded only after the engine attained the steady state. To assure the reproducibility of the experimental data, each test was duplicated three times, and the average value of the reported parameters was then evaluated. The statistical significance of the experimental data was provided using the confidence interval with a 95\% confidence level to consider the trends of the results.

\section{Results and Discussion}

\subsection{Test Fuels}

The physicochemical properties of distilled WPO and CWPO obtained by fractional distillation were studied. Analysis of fuel properties is essential, as it can ensure the suitability of a fuel for use with a compression ignition engine. Standard grade diesel fuel with 7\% biodiesel (B7) was used for our baseline study. This percentage of biodiesel present in the diesel fuel was prescribed by the Thailand Energy Business Department in January 2019.

\subsubsection{Chemical Compositions}

The distillation characteristics of hydrocarbon fuel have an important effect on their safety, combustion characteristics, exhaust emissions, and engine performance, especially in the case of waste fuels. The WPO from pyrolysis and the diesel fuel were tested by performing a simple batch fractional distillation on a laboratory scale. The distillation curves of the test fuels were tested according to the standard ASTM distillation apparatus. The distillation curves of the test fuels obtained under standardized conditions of temperature with a percentage of recovered volume and distillation curves of standard gasoline by Lobato et al. [30] are compared in Figure 2. The distillation curves of CWPO were closer to those of gasoline, with a distillation temperature between 76 and $252{ }^{\circ} \mathrm{C}$. On the contrary, the distillation temperature of distilled WPO was much closer to that of diesel fuel as the recovered volume increased, with a distillation temperature between 188 and $324{ }^{\circ} \mathrm{C}$. Lines in Figure 2 also confirm that WPO can be used as an alternative fuel in diesel engines. This is due to the distillation temperature that is desired to produce motor engines. This can be done with hydrocarbon fuel with boiling point ranges between 35 and $185{ }^{\circ} \mathrm{C}$ for gasoline, between 180 and $350{ }^{\circ} \mathrm{C}$ for diesel fuel, and between 180 and $350{ }^{\circ} \mathrm{C}$ for vacuum gas oil [31].

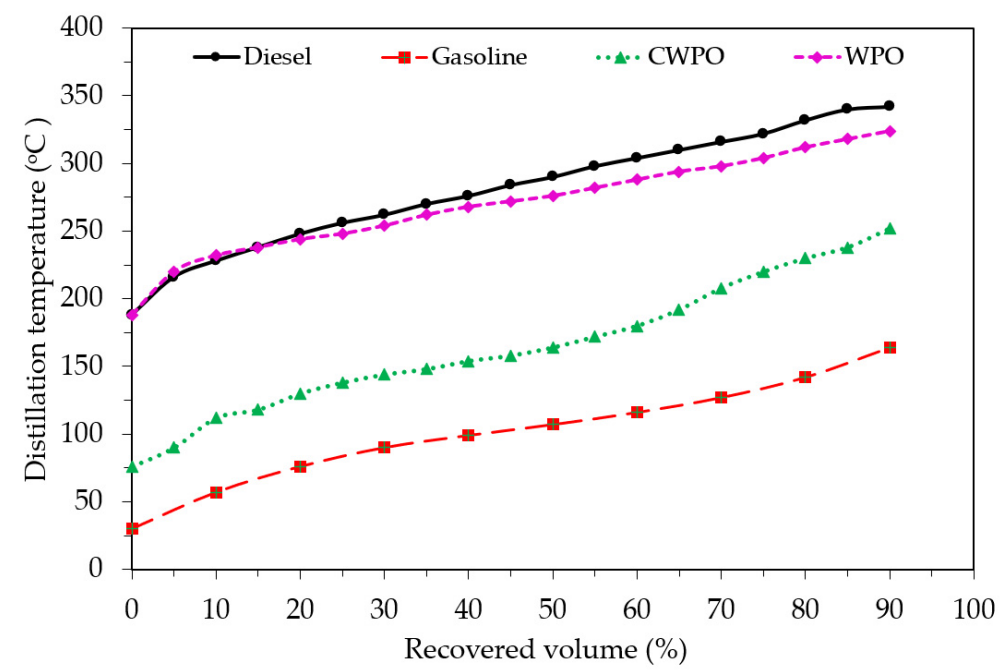

Figure 2. Distillation curves of test fuels obtained by fractional distillation.

GC-MS (compare with Section 2.2) for the test fuels was done to its chemical composition and is shown in Figure 3. The area percentage (\%Area) is presented in Table 3. The test fuels consist of different amounts of hydrocarbons, which were separated by their carbon atomic weight from the minimum carbon atom (C4) to the maximum carbon atom 
(>C20) and can be categorized as C4-C11, C12-C20, or higher than C20. The C4-C12 group represents light hydrocarbons (gasoline fuel), which generally contain hydrocarbons between C5 and C9. The C12-C20 group represents middle hydrocarbons (diesel fuel), which generally contain hydrocarbons between C16 and C20. Table 4 compares the test fuels and shows that there was a similar trend between WPO and the standard-grade diesel fuel. Both WPO and diesel fuel have carbon atoms in the C12-C20 group [13,28]. However, CWPO has a high percentage of carbon atoms in the C4-C11 group. Based on the results of the chemical composition tests, CWPO was estimated to have a similar chemical composition to fuel in the category of the gasoline group, and the WPO has a chemical composition similar to diesel fuel. The chemical compositions obtained by GC-MS are consistent with the distillation curves, and the distillation curves of WPO and diesel fuel are similar. As a result of this finding, WPO was used on a VCR diesel engine to evaluate combustion characteristics, exhaust emissions, and engine performance in comparison to diesel fuel. Different plastic sources used in the pyrolysis process to produce oil resulted in different chemical compositions of CWPO, which may have affected the result of the engine tests in different ways. This can be supported by the chemical compositions (by GC-MS analysis) of WPO derived from the mixtures of plastic waste used in our current study and in previous studies [28]. In addition, different GC-MS results of liquid oil from pyrolysis of different types of plastic waste were reported in [32]. Therefore, the distillation process may be needed to control the chemical compositions of fuels derived from plastic oil.
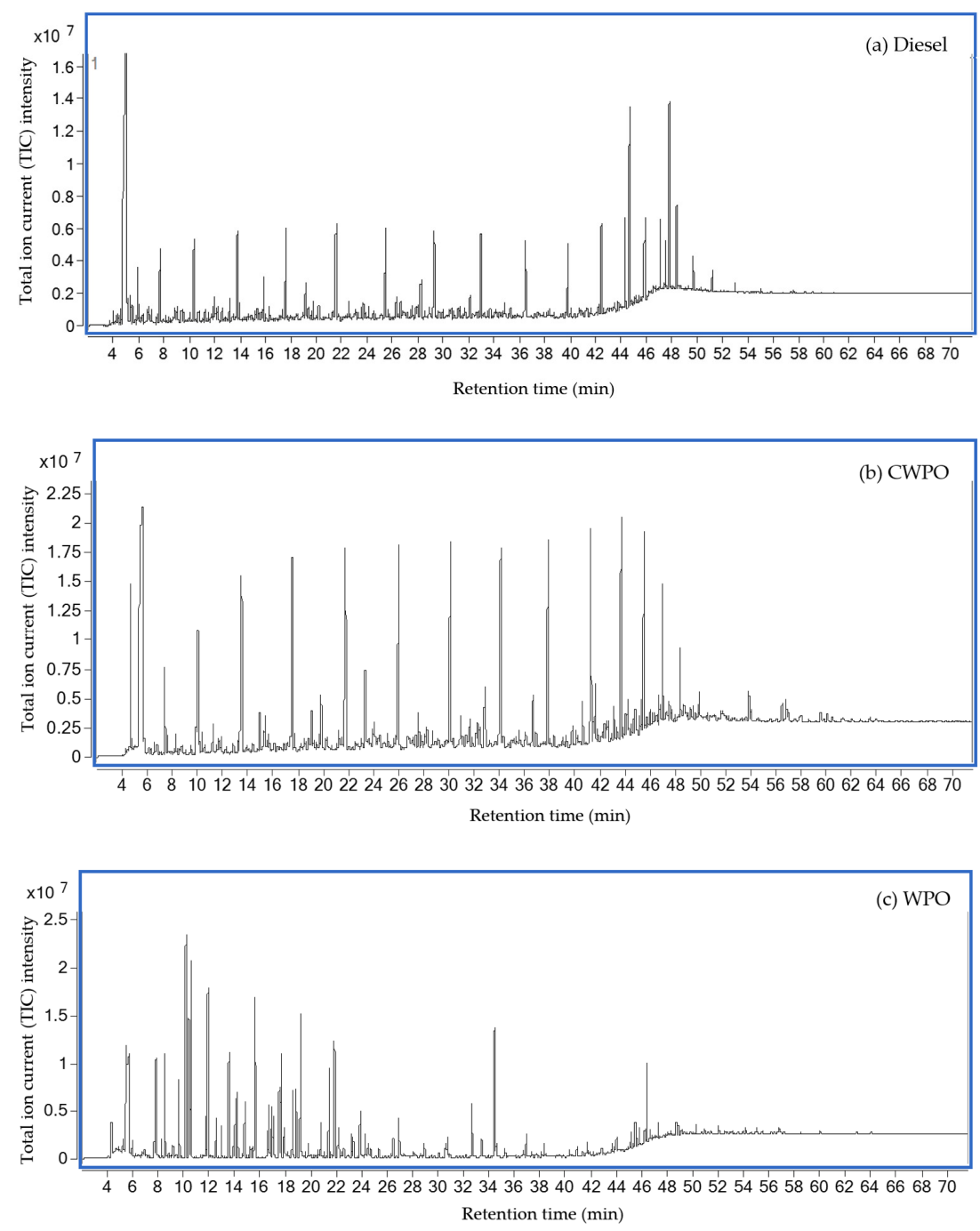

Figure 3. GC-MS chromatogram for (a) Diesel, (b) CWPO, and (c) WPO. 
Table 3. Components of diesel and WPO by GC-MS analysis.

\begin{tabular}{cccc}
\hline Carbon Content & Diesel & CWPO & WPO \\
\hline C4 & ND & 2.77 & ND \\
C5 & ND & 0.84 & ND \\
C6 & ND & 3.76 & ND \\
C7 & ND & 5.38 & ND \\
C8 & 2.54 & 34.02 & 1.03 \\
C9 & 5.61 & 19.94 & 0.73 \\
C10 & 5.23 & 28.49 & 2.28 \\
C11 & 4.18 & 0.53 & 5.71 \\
C12 & 7.08 & 0.75 & 9.78 \\
C13 & 6.39 & ND & 10.08 \\
C14 & 8.09 & ND & 11.03 \\
C15 & 5.66 & 0.67 & 10.48 \\
C16 & 5.95 & 0.19 & 8.71 \\
C17 & 15.80 & 0.26 & 7.90 \\
C18 & 4.30 & 0.32 & 8.88 \\
C19 & 16.11 & 0.36 & 7.86 \\
C20 & 3.90 & 0.24 & 8.10 \\
C21 & 3.19 & 0.36 & 3.63 \\
C22 & ND & 0.27 & 2.29 \\
C23 & 2.36 & 0.20 & 1.08 \\
C24 & ND & 0.19 & 0.43 \\
C25 & 1.19 & 0.20 & ND \\
C26 & 1.13 & 0.18 & ND \\
C27 & 0.62 & ND & ND \\
C28 & 0.34 & 0.08 & ND \\
C29 & 0.33 & 0.08 &
\end{tabular}

ND-Not detected.

Table 4. Carbon content of the test fuel compared with diesel fuel by GC-MS analysis.

\begin{tabular}{cccc}
\hline \multirow{2}{*}{ Carbon Content } & \multicolumn{3}{c}{ Area Percentage } \\
\cline { 2 - 4 } & Diesel & CWPO & WPO \\
\hline C4-C11 & 13.38 & 95.72 & 9.74 \\
C12-C20 & 75.00 & 2.79 & 82.83 \\
$>$ C20 & 11.62 & 1.49 & 7.43 \\
\hline
\end{tabular}

\subsubsection{Chemical and Physical Properties of the Test Fuels}

The physicochemical properties of CWPO, WPO, and diesel were tested according to the American Standard of Testing Methods (ASTM). The characteristic properties of the test fuels are shown in Table 5. The kinematic viscosity, flash point, calorific value, cetane index, and distillation temperature of CWPO and WPO were lower than they were in diesel fuel. In addition, the kinematic viscosity, surface tension, flash point, and distillation temperature of WPO were higher than those of CWPO. Thus, the characteristic properties of CWPO were more similar to those of gasoline. However, the kinematic viscosity, specific gravity, density, gross calorific value, and distillation temperature of WPO were closer to those of diesel fuel. 
Table 5. Basic physicochemical properties of CWPO, WPO, and diesel fuel.

\begin{tabular}{|c|c|c|c|c|}
\hline Properties & Test Method & Diesel & CWPO & WPO \\
\hline Kinematic viscosity at $40^{\circ} \mathrm{C}(\mathrm{cSt})$ & ASTM D445 & 3.44 & 1.66 & 3.11 \\
\hline Surface tension $(\mathrm{mN} / \mathrm{m})$ & ASTM D971 & - & 27.77 & 27.85 \\
\hline Specific gravity at $15.6^{\circ} \mathrm{C}$ & ASTM D1298 & 0.835 & 0.900 & 0.824 \\
\hline Density at $15.6{ }^{\circ} \mathrm{C}\left(\mathrm{kg} / \mathrm{m}^{3}\right)$ & ASTM D1298 & 834 & 899 & 823 \\
\hline Flash point $\left({ }^{\circ} \mathrm{C}\right)$ & ASTM D93 & 66 & 35 & 54 \\
\hline Gross calorific value (MJ / kg) & ASTM D240 & 45.56 & 37.72 & 45.24 \\
\hline Cetane index & ASTM D976 & 56.57 & - & 46.7 \\
\hline Distillation temperature $\left({ }^{\circ} \mathrm{C}\right)$ & ASTM D86 & & & \\
\hline $10 \%$ Recovered $\left({ }^{\circ} \mathrm{C}\right)$ & ASTM D86 & 228 & 112 & 232 \\
\hline $50 \%$ Recovered $\left({ }^{\circ} \mathrm{C}\right)$ & ASTM D86 & 290 & 164 & 276 \\
\hline $90 \%$ Recovered $\left({ }^{\circ} \mathrm{C}\right)$ & ASTM D86 & 348 & 252 & 324 \\
\hline
\end{tabular}

\subsection{Engine Tests}

We investigated the use of WPO in a VCR diesel engine. WPO was compared with diesel fuel. The present study focuses on engine performance, the characteristics of combustion, and engine exhaust emissions.

\subsubsection{Engine Performance}

The variation in brake-specific fuel consumption (BSFC) with engine loads at different compression ratios is shown in Figure 4. BSFC is the fuel flow rate needed by the engine to produce unit power. The BSFC decreases with any increase in engine operating loads or compression ratio. This may be due to the efficiency increase caused by the cylinder temperature increase, the reduced ignition delay period, or the total timing increases, which bring about the better combustion at higher engine loads and higher compression ratios $[33,34]$. Moreover, the BSFC of WPO was higher than that of diesel at all compression ratios due to its lower gross calorific value, as can be seen in Table 5, showing that more fuel is needed in the combustion process to obtain the same power output as diesel fuel $[16,29,35]$.

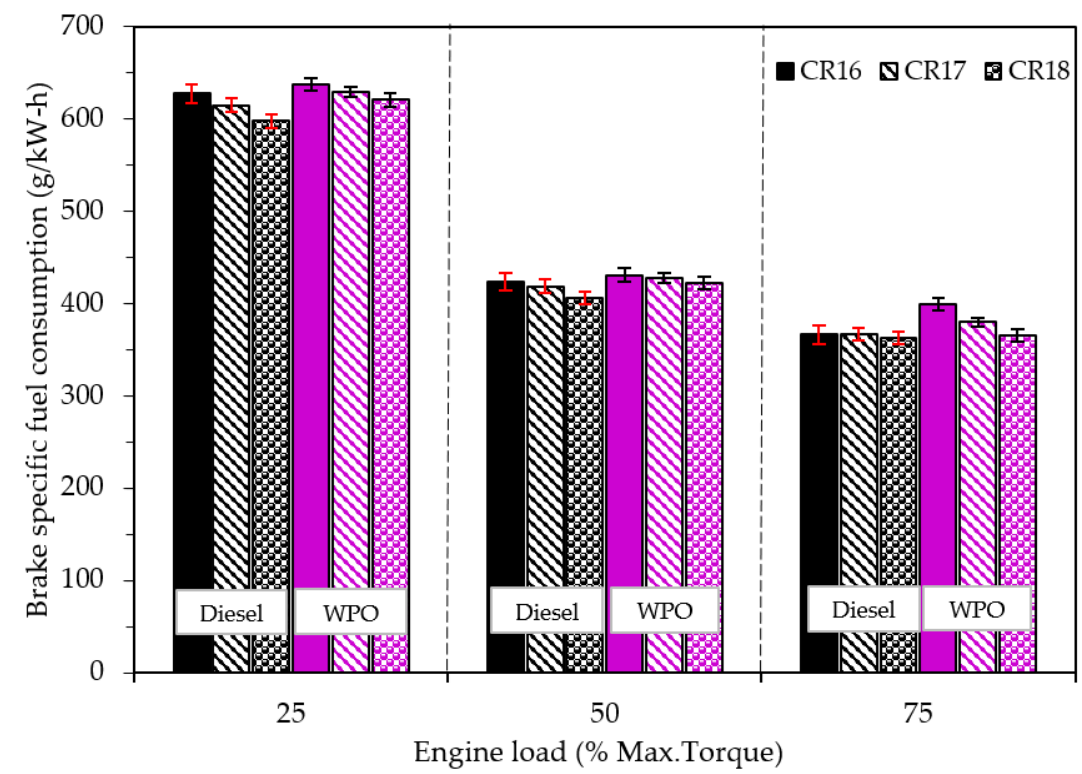

Figure 4. Variation in brake specific fuel consumption (BSFC) with engine loads.

The variation of brake thermal efficiency (BTE) with engine loads at different compression ratios is shown in Figure 5. BTE indicates the conversion of the energy in the fuel to brake power output. Increasing the engine operating loads tends to result in more BTE. 
The BTE of WPO was found to be lower than that of diesel fuel at all engine loads and all compression ratios. More energy is needed to break down the heavy hydrocarbon chains (C13 to C22) in WPO, which might explain the lower BTE of WPO [29]. BTE also increased with the increase in compression ratio for all test fuels, since the increase in compression ratio also increases the in-cylinder temperatures, which improves combustion and thermal efficiency [36,37]. This improvement in BTE could also be attributed to the reduction in ignition delay as the compression ratio increases [38].

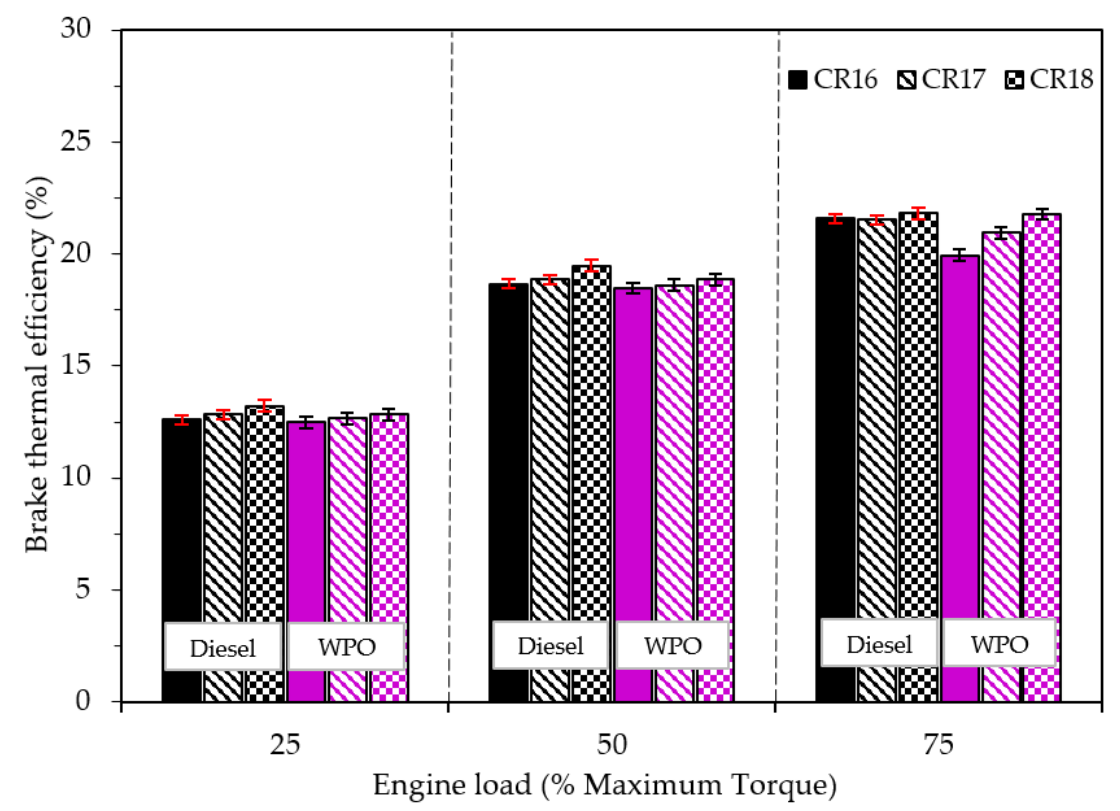

Figure 5. Variation of the brake thermal efficiency (BTE) with engine loads.

\subsubsection{Combustion Characteristics}

The variation in heat release rate and in-cylinder pressure is summarized as follows.

The variation in the rate of heat release (RoHR) and in-cylinder pressure (ICP) with the crank angle for WPO and diesel fuel at different engine loads is presented in Figure 6. ICP measurements play a key role in combustion analysis of the thermal energy produced during the fuel combustion process in each engine cycle. The RoHR was calculated using the in-cylinder pressure, which is measured according to the first law of thermodynamics and isentropic relations [39]. ICP and RoHR were found to increase as the engine load increased in all tests due to the higher charge of the mixture that was carried to the cylinder [40]. Compared with diesel fuel, a lower in-cylinder pressure was obtained with WPO at medium and high engine loads for CR18. In addition, the start of the combustion of WPO, compared to that of the diesel fuel, was more delayed. This may be due to the lower density of WPO, which can result in a lower bulk modulus. In addition, the lower cetane index of WPO could explain the delay time in combustion with WPO [18,41]. A higher engine load leads to a shorter ignition delay period and longer combustion periods. This is due to the increase in temperature inside the combustion chamber, which tends to improve the quality of the air-fuel mixture, leading to a decrease in the ignition delay [42]. 

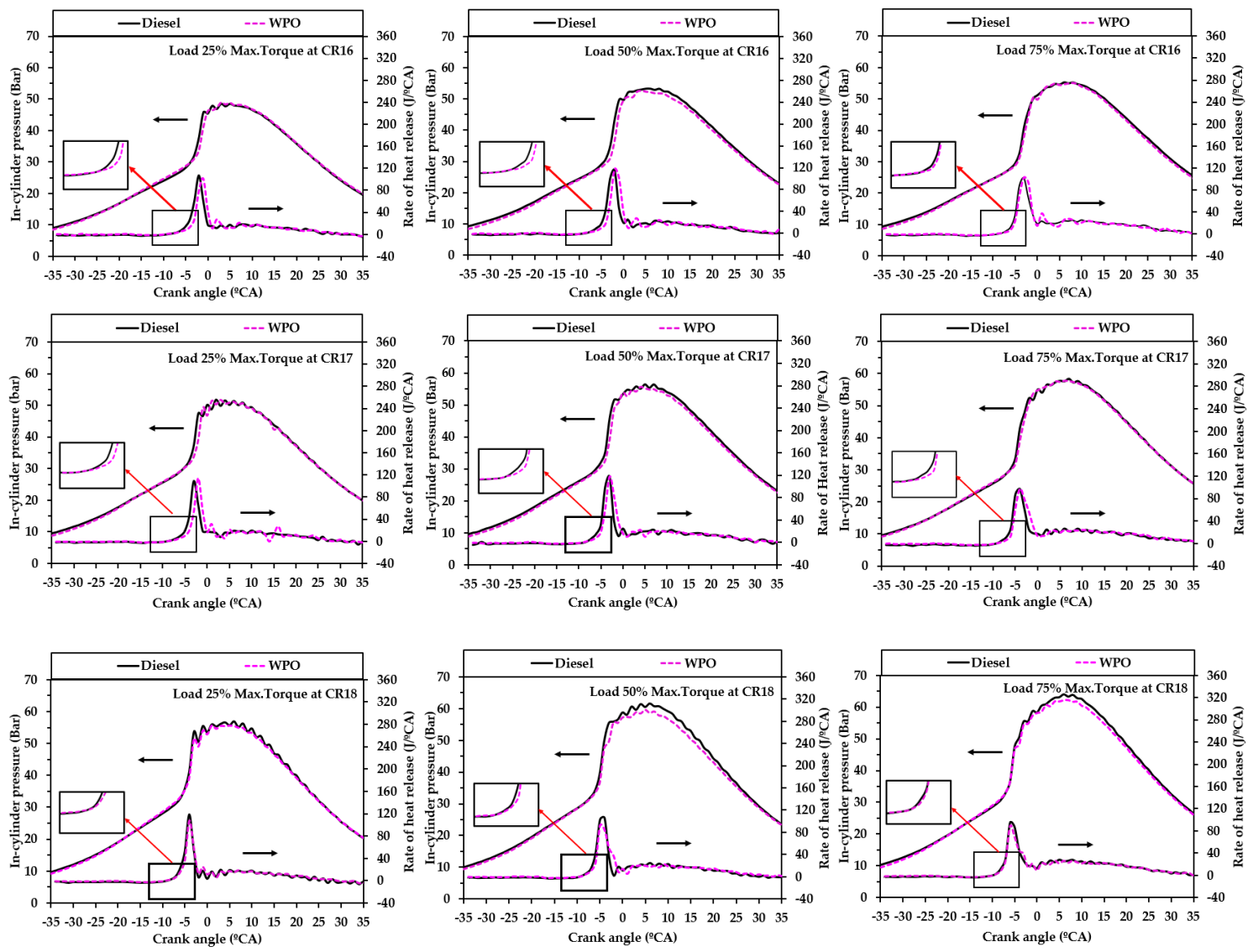

Figure 6. Variation in heat release rate and in-cylinder pressure with the crank angle.

The ICP and RoHR variation with the crank angle for WPO and diesel fuel at different compression ratios are illustrated in Figure 7. The maximum ICP was found at CR18. Maximum ICP mainly depends on the quality of the fuel oil, injection timing, ignition timing, and the atomization of fuel [26]. From Figure 7, it can be seen that, as compression ratio increases, ICP also increases. This increase in ICP may be attributed to the better mixing of air and fuel during the initial stage of combustion [42]. On the other hand, as the compression ratio increases, the peak of the RoHR decreases. In general, a higher accumulation of injected fuel over a longer delay period can result in a higher RoHR in the premixed combustion [43]. A higher compression ratio leads to an advance at the start of combustion because of the higher in-cylinder temperature and pressure, which results in better atomization with a higher fuel vaporization rate, leading to an earlier ignition or a shorter ignition delay [44].


Figure 7. Variation in the rate of heat release (RoHR) and in-cylinder pressure (ICP) with the crank angle at different compression ratios at a 75\% maximum engine torque: (a) diesel; (b) WPO. 


\subsubsection{Emission Characteristics}

The engine-out emissions comprised carbon monoxide $(\mathrm{CO})$, nitrogen oxides $\left(\mathrm{NO}_{\mathrm{X}}\right)$, unburned hydrocarbon (HC), and smoke, which were produced by the combustion of distilled WPO and diesel fuel, were investigated under different engine operating loads and compression ratios. The specific emissions that relate to the mass flow rate of emissions per unit power output were calculated for carbon monoxide, nitrogen oxides, and unburned hydrocarbon.

The variation in specific nitrogen oxide (NOx) emissions with engine loads at different compression ratios is shown in Figure 8. Nitrogen oxide (NOx) is nitric oxide (NO) and nitrogen dioxide $\left(\mathrm{NO}_{2}\right)$ in the exhaust of internal combustion engines [45]. The experiment showed that the NOx emissions decreased as the engine operating load increased for all test fuels. In general, specific quantities can decrease as power output increases. A lower oxygen availability can be taken into account for a reduction in NOx when an engine is run at a high engine load. As compared with diesel fuel, the NOx emissions of WPO were higher than those of diesel fuel. This was due to the longer ignition delay owing to the long chain carbon compounds in the WPO [46]. In addition, the increase in the compression ratio increased the NOx emissions of WPO and diesel fuel. Increasing the cylinder pressure at a higher combustion temperature tends to be conducive to NOx formation. Furthermore, the advance in the combustion state due to a higher compression ratio can increase the combustion duration, leading to improvements in the combustion process that result in higher NOx emissions. Evidence of the advance at the start of combustion and the higher in-cylinder pressure as the compression ratio increases is shown in Figure 7.

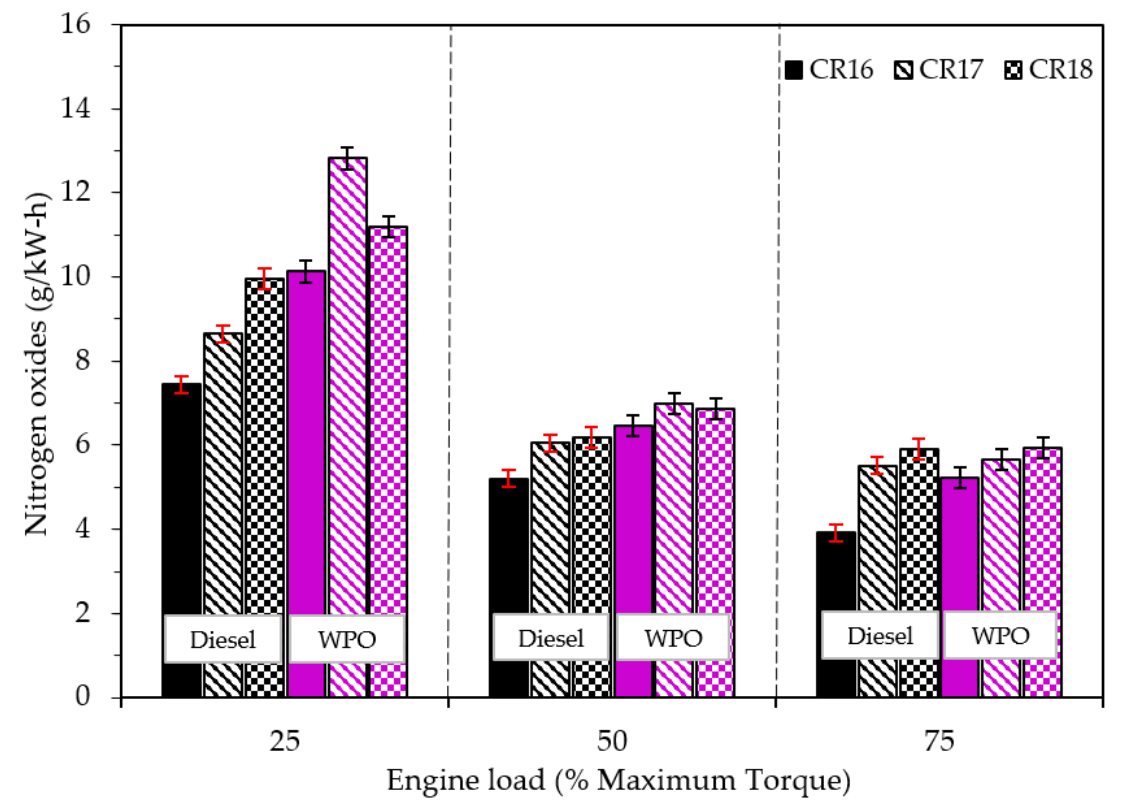

Figure 8. Variation in the nitrogen oxide (NOx) emissions with engine loads.

The variation in carbon monoxide (CO) emissions with engine loads at different compression ratios is shown in Figure 9. CO emission is an intermediate product in the combustion of hydrocarbon fuels that contain no oxygen in their molecular structure [47]. It is formed mainly due to incomplete combustion, which is exacerbated by a lack of oxygen, the in-cylinder temperature, and the residence time of combustion [45]. We observed that increasing the engine operating loads resulted in a decrease in $\mathrm{CO}$ emissions for all test fuels. The reason behind these decreased $\mathrm{CO}$ emissions may be due to the increase in combustion efficiency as engine operating load increases [34,48]. Comparing the test fuels, higher $\mathrm{CO}$ emissions were found due to the combustion of WPO. The lower cetane index of $\mathrm{WPO}$, which tended to delay the combustion state, resulting in a reduction in the residence time of combustion, can explain the higher CO emissions from the use of WPO. This can 
be more effective in increasing $\mathrm{CO}$ emissions when the engine is run at a low engine load condition, where the ICT is not high enough to convert the injected fuel to vapor. In addition, a higher amount of long chain carbon compounds (C12-C20) in WPO tended to cause more difficulty in combustion, leading to an increase in $\mathrm{CO}$ emissions [48]. The CO emissions increased as the compression ratio changed from CR16 to CR17. However, the $\mathrm{CO}$ emissions were considerably reduced when the engine operated at CR18, especially at a low engine load. The CO emissions of WPO tended to decrease as the compression ratio increased and the engine was run at a maximum load. A higher combustion efficiency was found at a higher compression ratio due to a higher charged air temperature, leading to improved air-fuel mixtures and faster fuel vaporization, resulting in more complete combustion (Figure 5).

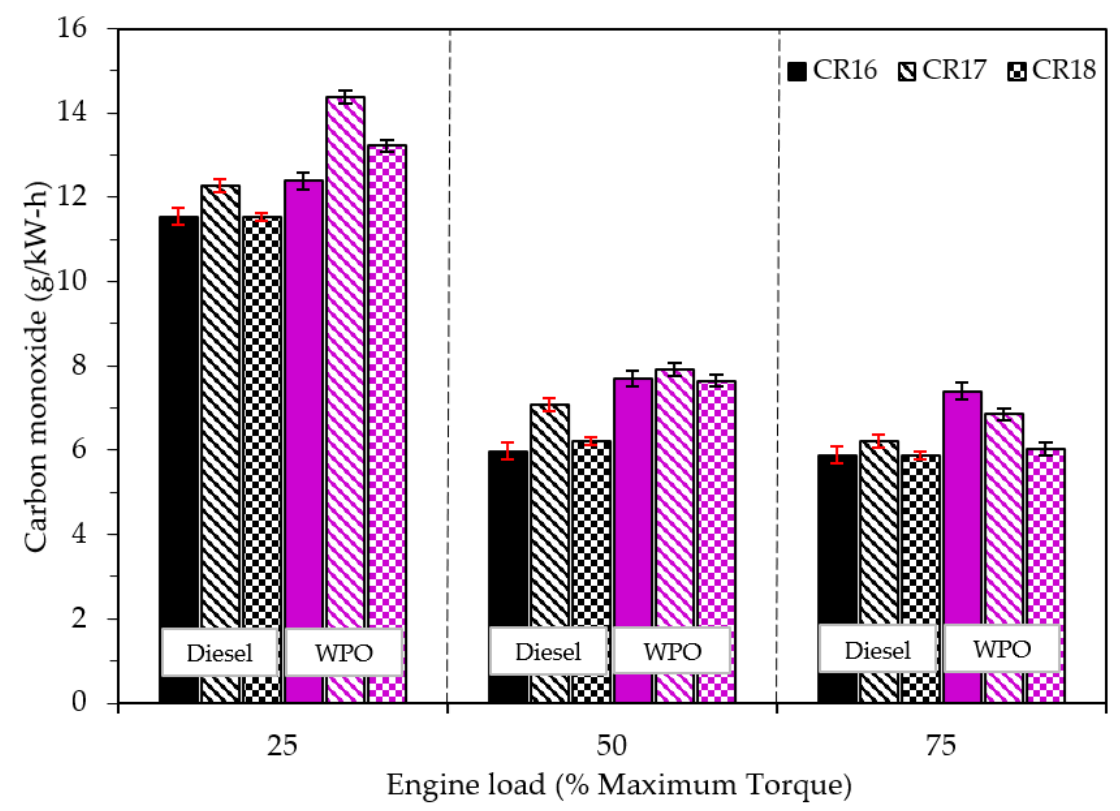

Figure 9. Variation in the carbon monoxide (CO) emissions with engine loads.

The variation in unburned hydrocarbon (HC) emissions with engine loads at different compression ratios is shown in Figure 10. In general, HC emissions indicate a very similar qualitative behavior to $\mathrm{CO}$ emissions. Both $\mathrm{HC}$ and $\mathrm{CO}$ emissions are useful for evaluating combustion efficiency. It was found that, as the engine operating load increased, the HC emission increased for all test fuels, at low and medium engine loads. However, at a high engine load, the $\mathrm{HC}$ emissions tended to decrease due to a more complete combustion. Comparing the test fuels, more $\mathrm{HC}$ emissions were obtained with the combustion of WPO compared to diesel fuel. The presence of $7 \%$ biodiesel present in standard diesel fuel enhanced the combustion process due to the oxygen content of the fatty acid methyl ester. Moreover, a lower cetane index and a higher amount of long chain carbon compounds (C12-C20) led to a longer ignition period and more difficulty in combustion, which can explain the higher CO emissions of WPO [18,27]. As compression ratio increased, in-cylinder pressure and temperature increased (Figure 7). This improved the air-fuel mixture, leading to a more complete combustion. In addition, a shorter delay at the start of combustion with an increasing compression ratio led to a longer combustion process, where lower $\mathrm{CO}$ emissions were found at higher compression ratios. 


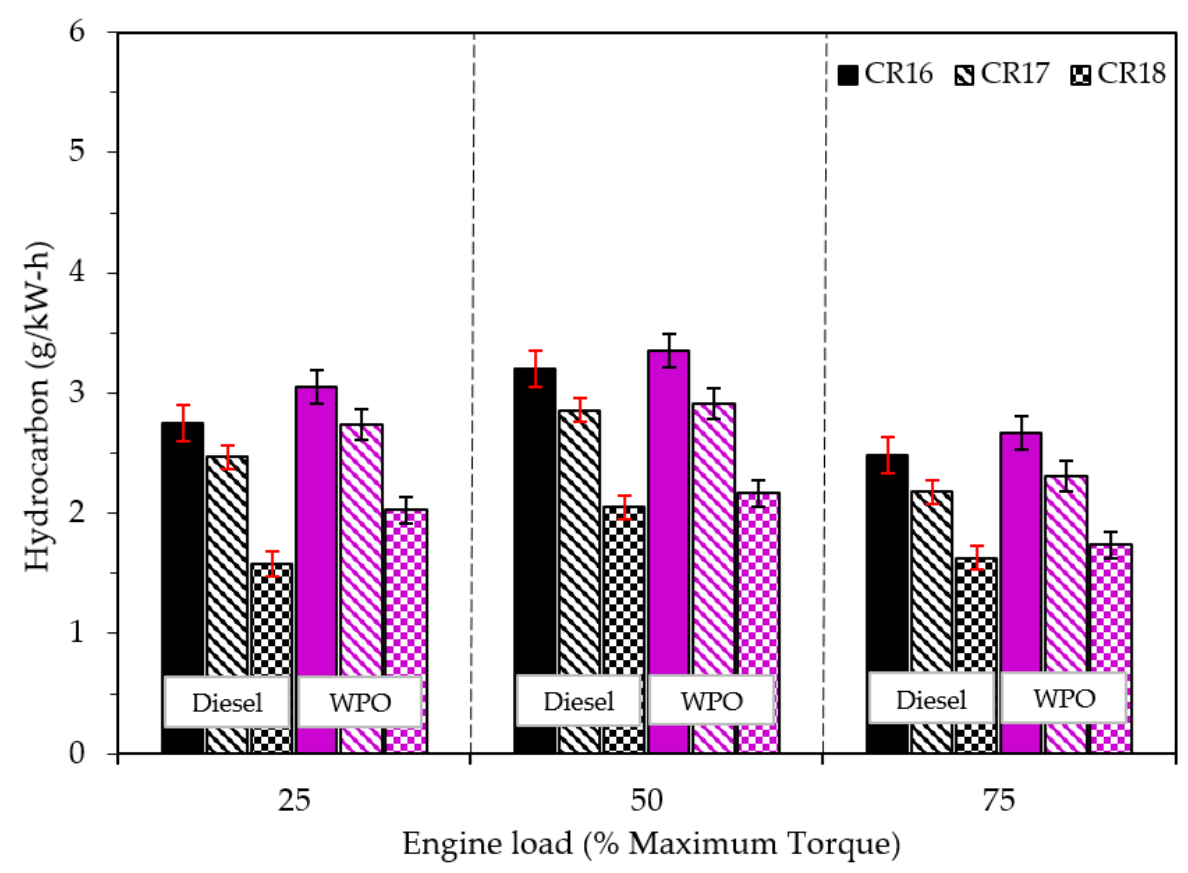

Figure 10. Variation in the unburned hydrocarbon (HC) emissions with engine loads.

The variation in smoke emissions with engine loads at different compression ratios is shown in Figure 11. Smoke emission is an indication of poor combustion caused by an over rich air-fuel mixture [45]. Smoke emissions increase with increases in engine operating loads when a rich mixture is burnt in the cylinder [33]. Compared with diesel fuel, a lower smoke emission was found with the combustion of WPO. It is noted that the diesel fuel used in this study is standard grade and contains $7 \%$ biodiesel. In general, the presence of oxygen in biodiesel is evidently associated with an improvement of smoke emissions. It was expected that the smoke emissions from standard diesel fuel would be lower than those of WPO. These lower smoke emissions could be explained by the lower viscosity and lower distillation temperature of WPO (Figure 2), which can improve fuel atomization, resulting in an enhancement in the combustion process. These two factors were more likely to contribute to the reduction in smoke emissions with WPO when the engine was run at low and medium loads, together with a high compression ratio. As the compression ratio increased, smoke emissions tended to decrease for all test fuels. The higher combustion temperature and shorter delay time of combustion could explain the lower smoke emissions at higher compression ratios. However, the combustion of WPO with an overly rich air-fuel ratio, when the engine was run at the highest load, tended to increase smoke emissions as the compression ratio increased. This implies that the effect of lower viscosity and distillation temperature cannot reduce emissions at the highest engine load and compression ratio. 


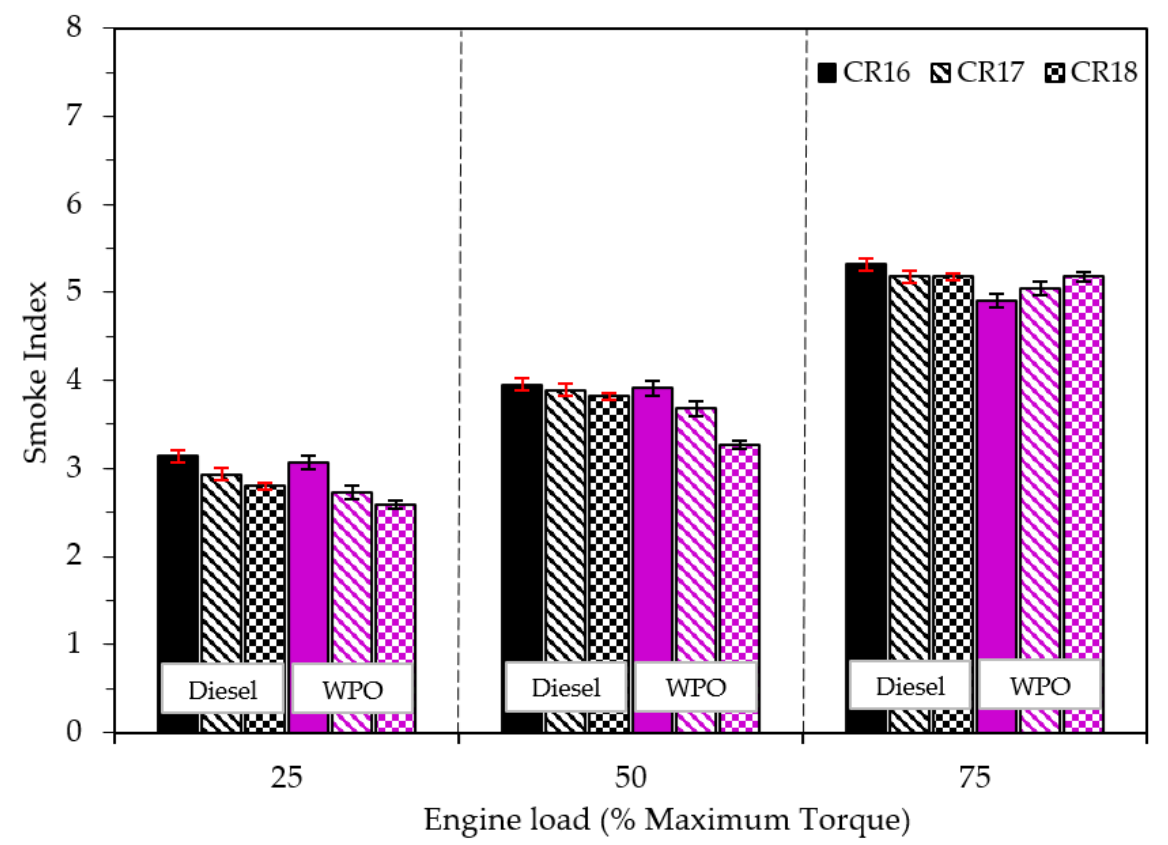

Figure 11. Variation in smoke emissions with engine loads.

\section{Conclusions}

The effects of compression ratio on combustion characteristics, exhaust emissions, and engine performance using WPO obtained from the pyrolysis process as an alternative fuel for compression ignition engines were studied. The results of GC-MS show that CWPO in this study contains the highest percentage of carbon atoms in the C4-C11 group and cannot be directly used as fuel in a compression ignition engine. WPO was prepared by distillation to improve the quality of the pyrolysis oil, and its properties were very close to those of diesel fuel. It is notable that different plastic sources used in the pyrolysis process can result in different chemical compositions of CWPO. Thus, the distillation process may be needed to control the chemical compositions of fuels derived from plastic waste.

The WPO was tested in the variable compression ignition diesel engine to evaluate combustion characteristics, exhaust emissions, and engine performance. Diesel fuel was also tested in the engine as a baseline fuel. The findings from the engine test can be summarized as follows.

- A lower cetane index and a higher percentage of long chain carbon compounds (C12-C20) resulted in higher $\mathrm{NOx}, \mathrm{CO}$, and $\mathrm{HC}$ emissions caused by the combustion of WPO.

- The disadvantage of emissions by the use of WPO can be alleviated when the engine operates at a high engine operating load and a high compression ratio.

Author Contributions: Conceptualization, E.S. and J.S.; experimental tests and post-processing, K.W., N.K. and S.M.; writing—original draft paper preparation, K.W., C.K. and S.M.; writing—review and editing, K.W. and E.S.; supervision, J.S.; resources, P.L. and W.A. All authors have read and agreed to the published version of the manuscript.

Funding: Financial support was provided by the Innovation Technology Assistance Program (ITAP: Research Fund Code 2564/0266) under the National Science and Technology Development Agency (NSTDA), Thailand, and the Suranaree University of Technology (SUT) Assistant Research Fund.

Institutional Review Board Statement: Not applicable.

Informed Consent Statement: Not applicable.

Data Availability Statement: Not applicable. 
Acknowledgments: The authors gratefully acknowledge K.P.R Plastics Packaging Co., Ltd., and the Center of Excellence in BioMass, Suranaree University of Technology, Thailand, for the raw materials and equipment used for experiments.

Conflicts of Interest: The authors declare no conflict of interest.

$\begin{array}{ll}\text { Nomenclature } \\ \text { BSFC } & \text { brake-specific fuel consumption } \\ \text { BTE } & \text { brake thermal efficiency } \\ \text { CO } & \text { carbon monoxide } \\ \text { CWPO } & \text { crude waste plastic oil } \\ \text { CR } & \text { compression ratio } \\ \text { GC-MS } & \text { gas chromatography-mass spectrometry } \\ \mathrm{HC} & \text { hydrocarbon } \\ \text { ICP } & \text { in-cylinder pressure } \\ \text { NO } & \text { nitric oxide } \\ \text { NO } & \text { nitrogen dioxide } \\ \text { NOX } & \text { nitrogen oxides } \\ \text { RoHR } & \text { rate of heat release } \\ \text { TDC } & \text { top dead center } \\ \text { VCR } & \text { variable compression ratio } \\ \text { WPO } & \text { distilled waste plastic oil }\end{array}$

\section{References}

1. Suthiwong, R. Renewable Energy policy. In NDC Security Review; Thailand National Defence College: Bangkok, Thailand, 2017; Volume 1, p. 12.

2. Alternative Energy and Efficiency Information Center, Department of Alternative Energy Development and Efficiency, Ministry of energy. Thailand Alternative Energy Situation 2017; Department of Alternative Energy Development and Efficiency, Ministry of energy: Bangkok, Thailand, 2017; Volume 15, ISSN 1686-5170.

3. Energy Policy and Planning Office, Ministry of Energy, Thailand. Thailand Integrated Energy Blueprint 2015-2036. 2015. Available online: http:/ / www.eppo.go/index.php/th/plan-policy/tieb (accessed on 10 December 2020).

4. Pollution Control Department. Municipal Solid Waste Situation of Thailand Report 2018; PCD—Pollution Control Department, Ministry of Natural Resources and Environment: Bangkok, Thailand, 2018. Available online: http://infofile.pcd.go.th/Waste/ Wst2018.pdf (accessed on 9 November 2020).

5. Pollution Control Department. Draft Integrated Plastic Waste Management Plan (2017-2021). 2017. Available online: http: / /infofile.pcd.go.th/law / DraftWastePlan60-64.pdf?CFID=1835558\&CFTOKEN=98563117 (accessed on 23 November 2020).

6. Hopewell, J.; Dvorak, R.; Kosior, E. Plastics recycling: Challenges and opportunities. Philos. Trans. R. Soc. B Biol. Sci. 2009, 364, 2115-2126. [CrossRef]

7. Sharuddin, S.D.A.; Abnisa, F.; Daud, W.M.A.W.; Aroua, M.K. A review on pyrolysis of plastic wastes. Energy Convers. Manag. 2016, 115, 308-326. [CrossRef]

8. Al-Salem, S.; Antelava, A.; Constantinou, A.; Manos, G.; Dutta, A. A review on thermal and catalytic pyrolysis of plastic solid waste (PSW). J. Environ. Manag. 2017, 197, 177-198. [CrossRef]

9. Traivivatana, S.; Wangjiraniran, W. Thailand Integrated Energy Blueprint (TIEB): One Step towards Sustainable Energy Sector. Energy Procedia 2019, 157, 492-497. [CrossRef]

10. Singh, R.K.; Ruj, B.; Sadhukhan, A.K.; Gupta, P.; Tigga, V.P. Waste plastic to pyrolytic oil and its utilization in CI engine: Performance analysis and combustion characteristics. Fuel 2020, 262, 116539. [CrossRef]

11. Phetyim, N.; Pivsa-Art, S. Prototype Co-Pyrolysis of Used Lubricant Oil and Mixed Plastic Waste to Produce a Diesel-Like Fuel. Energies 2018, 11, 2973. [CrossRef]

12. Khairil; Riayatsyah, T.M.I.; Bahri, S.; Sofyan, S.E.; Jalaluddin, J.; Kusumo, F.; Silitonga, A.S.; Padli, Y.; Jihad, M.; Shamsuddin, A.H. Experimental Study on the Performance of an SI Engine Fueled by Waste Plastic Pyrolysis Oil-Gasoline Blends. Energies 2020, 13, 4196. [CrossRef]

13. Pratama, N.N.; Saptoadi, H. Characteristics of Waste Plastics Pyrolytic Oil and Its Applications as Alternative Fuel on Four Cylinder Diesel Engines. Int. J. Renew. Energy Dev. 2014, 3, 13-20.

14. Kalargaris, I.; Tian, G.; Gu, S. The utilisation of oils produced from plastic waste at different pyrolysis temperatures in a DI diesel engine. Energy 2017, 131, 179-185. [CrossRef]

15. Venkatesan, H.; Sivamani, S.; Bhutoria, K.; Vora, H.H. Experimental study on combustion and performance characteristics in a DI CI engine fuelled with blends of waste plastic oil. Alex. Eng. J. 2018, 57, 2257-2263. [CrossRef] 
16. Devaraj, J.; Robinson, Y.; Ganapathi, P. Experimental investigation of performance, emission and combustion characteristics of waste plastic pyrolysis oil blended with diethyl ether used as fuel for diesel engine. Energy 2015, 85, 304-309. [CrossRef]

17. Kalargaris, I.; Tian, G.; Gu, S. Experimental evaluation of a diesel engine fuelled by pyrolysis oils produced from low-density polyethylene and ethylene-vinyl acetate plastics. Fuel Process. Technol. 2017, 161, 125-131. [CrossRef]

18. Sukjit, E.; Liplap, P.; Maithomklang, S.; Arjharn, W. Experimental Investigation on a DI Diesel Engine Using Waste Plastic Oil Blended with Oxygenated Fuels. SAE Tech. Pap. 2017, 1. [CrossRef]

19. Mani, M.; Nagarajan, G.; Sampath, S. Characterisation and effect of using waste plastic oil and diesel fuel blends in compression ignition engine. Energy 2011, 36, 212-219. [CrossRef]

20. Mangesh, V.L.; Padmanabhan, S.; Tamizhdurai, P.; Narayanan, S.; Ramesh, A. Combustion and emission analysis of hydrogenated waste polypropylene pyrolysis oil blended with diesel. J. Hazard. Mater. 2020, 386, 121453. [CrossRef]

21. Das, A.K.; Hansdah, D.; Mohapatra, A.K.; Panda, A.K. Energy, Exergy and Emission Analysis on a DI Single Cylinder Diesel engine using pyrolytic waste plastic oil diesel blend. J. Energy Inst. 2020, 93, 1624-1633. [CrossRef]

22. Mangesh, V.L.; Padmanabhan, S.; Tamizhdurai, P.; Ramesh, A. Experimental investigation to identify the type of waste plastic pyrolysis oil suitable for conversion to diesel engine fuel. J. Clean. Prod. 2020, 246, 119066. [CrossRef]

23. Kaimal, V.K.; Vijayabalan, P. A detailed study of combustion characteristics of a DI diesel engine using waste plastic oil and its blends. Energy Convers. Manag. 2015, 105, 951-956. [CrossRef]

24. Rinaldini, C.A.; Mattarelli, E.; Savioli, T.; Cantore, G.; Garbero, M.; Bologna, A. Performance, emission and combustion characteristics of a IDI engine running on waste plastic oil. Fuel 2016, 183, 292-303. [CrossRef]

25. Kumar, P.S.; Sankaranarayanan, G. Investigation on environmental factors of waste plastics into oil and its emulsion to control the emission in DI diesel engine. Ecotoxicol. Environ. Saf. 2016, 134, 440-444. [CrossRef]

26. Kalargaris, I.; Tian, G.; Gu, S. Combustion, performance and emission analysis of a DI diesel engine using plastic pyrolysis oil. Fuel Process. Technol. 2017, 157, 108-115. [CrossRef]

27. Kaimal, V.K.; Vijayabalan, P. A detailed investigation of the combustion characteristics of a DI diesel engine fuelled with plastic oil and rice bran methyl ester. J. Energy Inst. 2017, 90, 324-330. [CrossRef]

28. Kaewbuddee, C.; Sukjit, E.; Srisertpol, J.; Maithomklang, S.; Wathakit, K.; Klinkaew, N.; Liplap, P.; Arjharn, W. Evaluation of waste plastic oil-biodiesel blends as alternative fuels for diesel engines. Energies 2020, 13, 2823. [CrossRef]

29. Damodharan, D.; Sathiyagnanam, A.P.; Rana, D.; Kumar, B.R.; Saravanan, S. Extraction and characterization of waste plastic oil (WPO) with the effect of $n$-butanol addition on the performance and emissions of a DI diesel engine fueled with WPO/diesel blends. Energy Convers. Manag. 2017, 131, 117-126. [CrossRef]

30. Lobato, J.; Rodríguez, J.F.; Jiménez, C.; Llanos, J.; Nieto-Márquez, A.; Inarejos, A.M. Consequence analysis of an explosion by simple models: Texas refinery gasoline explosion case. Afinidad 2009, 66, 372-379.

31. Sharma, B.K.; Moser, B.R.; Vermillion, K.E.; Doll, K.M.; Rajagopalan, N. Production, characterization and fuel properties of alternative diesel fuel from pyrolysis of waste plastic grocery bags. Fuel Process. Technol. 2014, 122, 79-90. [CrossRef]

32. Miandad, R.; Barakat, M.A.; Aburiazaiza, A.S.; Rehan, M.; Ismail, I.M.I.; Nizami, A.S. Effect of plastic waste types on pyrolysis liquid oil. Int. Biodeterior. Biodegrad. 2017, 119, 239-252. [CrossRef]

33. Ananthakumar, S.; Jayabal, S.; Thirumal, P. Investigation on performance, emission and combustion characteristics of variable compression engine fuelled with diesel, waste plastics oil blends. J. Braz. Soc. Mech. Sci. Eng. 2016, 39, 19-28. [CrossRef]

34. Verma, A.; Raghuvansi, A.; Quraishi, M.A.; Tirkey, J.V.; Verma, C. Engine Fuel Production from Waste Plastic Pyrolysis (WPO) and Performance Evaluation in a CI engine with Diesel Blend. J. Mater. Environ. Sci. 2018, 9, 1712-1721.

35. Bridjesh, P.; Geetha, N.K. Effect of Diethyl Carbonate as Additive to Waste Plastic Oil on Performance and Emission of a Diesel Engine. Orient. J. Chem. 2020, 36, 189-194. [CrossRef]

36. Rao, B.G.; Bharadwaz, Y.D.; Virajitha, C.; Rao, V.D. Effect of injection parameters on the performance and emission characteristics of a variable compression ratio diesel engine with plastic oil blends-An experimental study. Energy Environ. 2018, 29, 492-510.

37. Syamsiro, M.; Saptoadi, H.; Kismurtono, M.; Mufrodi, Z.; Yoshikawa, K. Utilization of waste polyethylene pyrolysis oil as partial substitute for diesel fuel in a DI diesel engine. Int. J. Smart Grid Clean Energy 2019, 8, 38-47. [CrossRef]

38. Hirkude, J.; Padalkar, A.S. Experimental investigation of the effect of compression ratio on performance and emissions of CI engine operated with waste fried oil methyl ester blend. Fuel Process. Technol. 2014, 128, 367-375. [CrossRef]

39. Heywood, J.B. Internal Combustion Engine Fundamentals; McGraw-Hill: New York, NY, USA, 1988; p. 508.

40. Uyumaz, A.; Aydoğan, B.; Solmaz, H.; Yılmaz, E.; Hopa, D.Y.; Bahtli, T.A.; Solmaz, Ö.; Aksoy, F. Production of waste tyre oil and experimental investigation on combustion, engine performance and exhaust emissions. J. Energy Inst. 2019, 92, $1406-1418$. [CrossRef]

41. Kobori, S.; Kamimoto, T.; Aradi, A.A. A study of ignition delay of diesel fuel sprays. Int. J. Engine Res. 2000, 1, 29-39. [CrossRef]

42. Vasudeva, M.; Sharma, S.; Mohapatra, S.K.; Kundu, K. Performance and exhaust emission characteristics of variable compression ratio diesel engine fuelled with esters of crude rice bran oil. SpringerPlus 2016, 5, 293. [CrossRef]

43. Ramalingam, S.; Rajendran, S. Assessment of performance, combustion, and emission behavior of novel annona biodieseloperated diesel engine. In Advances in Eco-Fuels for a Sustainable Environment; Woodhead Publishing: Cambridge, UK, 2019; pp. 391-405.

44. Saravanan, S.; Nagarajan, G.; Sampath, S. A Correlation for the Ignition Delay of a CI Engine Fuelled with Diesel and Biodiesel. Int. J. Green Energy 2014, 11, 542-557. [CrossRef] 
45. Majewski, W.A.; Khair, M.K. Diesel Emissions and Their Control; Society of Automotive Engineers: Wallendale, PA, USA, 2006; pp. 109-110.

46. Panda, A.K.; Murugan, S.; Singh, R.K. Performance and emission characteristics of diesel fuel produced from waste plastic oil obtained by catalytic pyrolysis of waste polypropylene. Energy Sources Part A Recovery Util. Environ. Eff. 2016, 38, 568-576. [CrossRef]

47. Sukjit, E.; Herreros, J.M.; Dearn, K.D.; García-Contreras, R.; Tsolakis, A. The effect of the addition of individual methyl esters on the combustion and emissions of ethanol and butanol -diesel blends. Energy 2012, 42, 364-374. [CrossRef]

48. Ashok, B.; Nanthagopal, K. Eco friendly biofuels for CI engine applications. In Advances in Eco-Fuels for a Sustainable Environment; Woodhead Publishing: Cambridge, UK, 2019; pp. 407-440. 